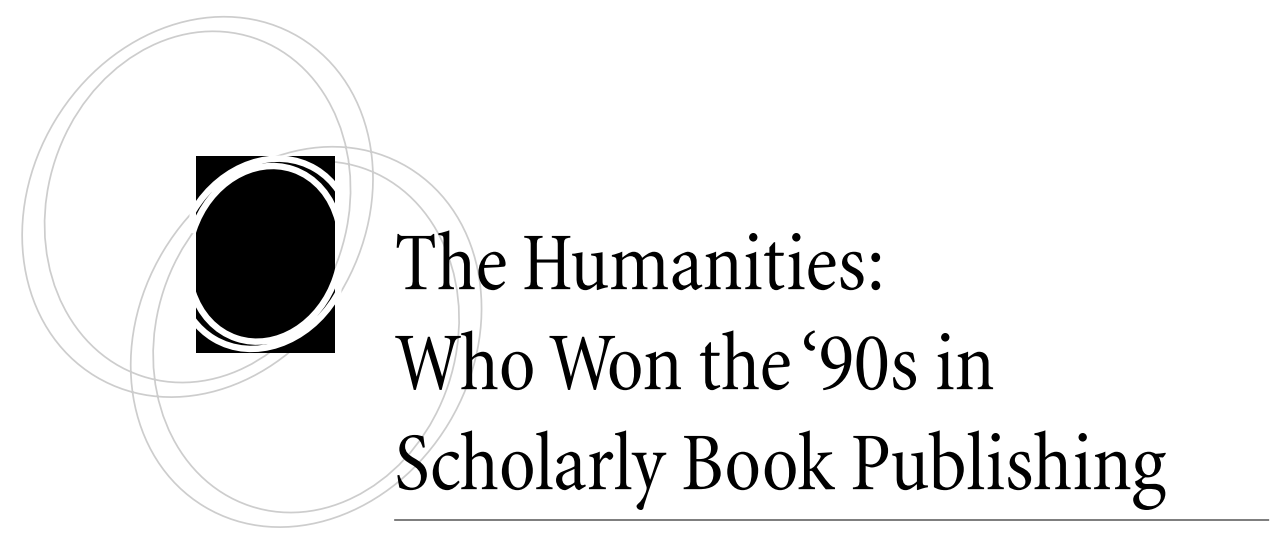

Stephen E. Wiberley, Jr.

abstract: The study of prizes awarded to books in the 1990s by leading humanities scholarly associations tells much about the disciplines, publishing, and libraries during that decade. This article examines data on prize-winners of the American Historical Association, the American Musicological Society, the College Art Association, and the Modern Language Association. For the prize-winners, it reports the distribution of winners among publishers and universities; extent of cross-disciplinary publishing; degree of co-authorship; trends in library acquisitions of print versions; and accessibility of electronic versions. The University of California Press and the faculty at the university's Berkeley campus ranked first; the American Historical Association awarded nearly half of its prizes to books classified outside history; there was little co-authorship; library holdings appeared to decline over the decade; and roughly 15 percent of prize-winners were available through netLibrary by the summer of 2001.

$\mathrm{A}$

cademic librarians, especially those who select materials for collections, have great interest in prestigious scholarly publications, authors, and publishers. To serve users well, librarians need to know what is happening in the disciplines, and acclaimed publications mark trends in different fields. The work of important authors is essential for good collections. Authors are so numerous it takes years for selectors to learn who are leaders, but a substantial majority of top authors works for a much smaller number of institutions that can be more easily remembered. Perhaps most important, librarians need to know about publishers who assure the quality of the books and journals libraries acquire.

A major indicator of prestige is prizes awarded to publications and their authors by scholarly associations. Awards for publications have a long history, and over time, among larger associations, at least, their numbers have grown. The present article reports about prize-winning authors and publishers in the humanities from 1990 through 1999. It covers awards given to books by the American Historical Association (AHA), the Ameri-

portal: Libraries and the Academy, Vol. 2, No. 3 (2002), pp. 357-374. Copyright (C 2002 by The Johns Hopkins University Press, Baltimore, MD 21218. 
can Musicological Society (AMS), the College Art Association (CAA), and the Modern Language Association of America (MLA). It examines books, because books are the most important form of publication in the humanities. ${ }^{1}$ It analyzes awards of the largest associations for history, musicology, art scholarship, and literary studies because these are the leading disciplines of the humanities. Some argue that history is a social science. While history has social scientific characteristics, the author of the present article thinks that librarians should differentiate areas of scholarship based on the sources of information used. The key difference between the basic (often called primary) sources of information of the humanities and the social sciences is that humanists study documents and artifacts created by other people, while social scientists participate in creating their basic information through experiments, field work, and surveys. ${ }^{2}$ Given this distinction, history is a field in the humanities. Although some historians use interviews (a form of social scientific field work), all use documents and artifacts left by people from the past.

While the present article will focus on which publishers and authors (and the institutions with whom the authors are affiliated) won the most prizes during the 1990s, the compilation of a list of leading books in the four most important humanities disciplines provides an opportunity to address additional issues of interest to librarians. First, determining how many libraries have entered holdings on OCLC for books of different disciplines gives one sense of the influence of those disciplines during the decade. Second, numbers of OCLC holdings offer an index of the level over time of library acquisitions. Third, academic libraries are not the only libraries that acquire humanities prizewinners. Analysis of the percentage of nonacademic libraries among OCLC holdings suggests which publishers and disciplines attracted attention outside the academy. Fourth, analysis of netLibrary's listings of books on OCLC provides a measure of the availability, at the end of the 1990s, of electronic versions of leading humanities scholarship. In contrast, analysis of netLibrary's OCLC listings suggests which publishers had books available electronically and which disciplines were best represented with electronic books. Fifth, there is evidence that the extent of co-authorship is generally increasing in the scholarly world. ${ }^{3}$ The data set gathered for the present study provides one recent measure of co-authorship in the humanities. Finally, by looking at the class numbers assigned to prize-winners, one can estimate cross-disciplinary interest in different fields and gauge the influence different disciplines have on each other.

\section{The Prizes}

At one time or another during the 1990s, the AHA awarded twenty-two differently named prizes to 145 books; the CAA awarded two prizes to twenty-two books; the MLA eighteen to 148 books; the American Musicological Association one prize to thirteen books. ${ }^{4}$ These amount to 328 awards in all. The median number of times each prize was awarded is eight; the average 7.6. Three were awarded only once (for example, an AHA prize given only in 1991); one nineteen times (the Lowell prize from the MLA, including honorable mentions and finalists). Two winners (H-NET and an historical society exhibit) were not books, and they are not included in the present analysis. Only twenty-four books (or 7 percent of all prize-winners) had co-authors, a total of fifty- 
eight persons or 2.4 authors per co-authored book; 1.1 authors for all books. This reinforces the point, sometimes contested, that while humanists consult other scholars, normally they work alone. ${ }^{5}$ Most authors won only one prize. Seven authors received two prizes; five of these (in history) were honored for the same book. The two authors who won prizes for two different books received the Mildenberger Prize of the MLA for an outstanding book about teaching foreign languages and literatures. That only two authors won prizes for more than one book reminds us not only how difficult it is to win a prize, but also how long it normally takes to write a book in the humanities, lessening the chances a given scholar will have two books eligible within a single decade. For literary studies, Clara Chu found that almost six years was the average period needed to write a book. ${ }^{6}$

\section{Institutional Affiliations of Prize-winners}

The fact that more than 360 different authors won prizes points to the challenge librarians face in learning about individual scholars. Institutional affiliations show some predominant universities, although there is considerable scatter. In all, the investigator found 156 institutions with at least one winner. Fifteen prizes went to scholars identified as independent, and the investigator could not find affiliations for nineteen other winners. Only 52 percent of the affiliated winners came from the top 20 percent of the institutions - far from the classic distribution where 80 percent of the instances of a phenomenon come

The fact that more than 360 different authors won prizes points to the challenge librarians face in learning about individual scholars. from 20 percent of the supplying sources. Among outstanding institutions, the University of California, Berkeley with fifteen prize-winners leads the way (table 1). California-Berkeley had at least one prizewinner in all four disciplines. Ten of these were in literature, the most for that field. Only two other institutions, Yale and the University of Chicago, had winners in all disciplines. University of California, Los Angeles (UCLA) was second among institutions with twelve winners, including five for books in history, most for that field. Ten different individuals accounted for the twelve UCLA prizes, as both double winners of MLA's Mildenberger prize came from UCLA. Duke followed UCLA with ten prizewinners. Among institutions with six or more prize-winners, Duke had unusual disciplinary concentration. Eight of its prizes were in literature, the other two in history. Other institutions with more than six winners received at most two-thirds of their prizes from the same association. Nine of the universities with four or more prizes had winners in just two fields, usually history and literature. But (besides California-Berkeley, Yale, and University of Chicago) Harvard, University of California-Santa Barbara, New York University, Virginia, Brandeis, and Cornell had prizes from three associations. Overall, the data reinforce something that is well known. Most of the best research comes from large research universities.

While no one would measure the strength of an institution's humanities programs by numbers of prizes won, it is interesting to compare the present study's findings with 


\section{Table 1}

Prizes Awarded by Institutions

\begin{tabular}{|c|c|c|c|c|c|}
\hline Institution & Total & CAA (Art) & AHA (History) & MLA (Literature) & AMS (Music) \\
\hline \multicolumn{5}{|l|}{ Berkeley } & 1 \\
\hline \multicolumn{5}{|l|}{ Los Angeles } & \\
\hline Duke & 10 & & 2 & 8 & \\
\hline Yale & 9 & 1 & 1 & 6 & 1 \\
\hline Chicago & 8 & 1 & 2 & 4 & 1 \\
\hline Harvard & 7 & 1 & 3 & 3 & \\
\hline \multicolumn{6}{|l|}{ Santa Barbara } \\
\hline CUNY & 6 & & 2 & 4 & \\
\hline New York & 6 & 2 & 2 & 2 & \\
\hline \multicolumn{6}{|l|}{ University } \\
\hline Virginia & 6 & & 3 & 2 & 1 \\
\hline Columbia & 5 & & 2 & 3 & \\
\hline Pennsylvania & 5 & & 1 & 4 & \\
\hline Texas-Austin & 5 & & 3 & 2 & \\
\hline Brandeis & 4 & & 1 & 1 & 2 \\
\hline Cornell & 4 & & 2 & 1 & 1 \\
\hline Iowa & 4 & 1 & 3 & & \\
\hline Ohio State & 4 & & & 4 & \\
\hline Stanford & 4 & & 1 & 3 & \\
\hline Wisconsin- & 4 & & 3 & 1 & \\
\hline \multicolumn{6}{|l|}{ Madison } \\
\hline 12 with 3 & 36 & & & & \\
\hline 24with 2 & 48 & & & & \\
\hline 101 with 1 & 101 & & & & \\
\hline Total & 309 & & & & \\
\hline $\begin{array}{l}\text { In counting wi } \\
\text { authors from th } \\
\text { If co-authors fr } \\
\text { institution ( } 15 \\
\text { counted once fo } \\
\text { books had one } \\
\text { had an author } \\
\text { institutional af }\end{array}$ & $\begin{array}{l}\text { nners by } \\
\text { e same } \\
\text { rom diff } \\
\text { such ca } \\
\text { or each i } \\
\text { or mor } \\
\text { either i }\end{array}$ & $\begin{array}{l}\text { sstitution, the } \\
\text { titution won a } \\
\text { ent institutior } \\
\text { s occurred). I } \\
\text { itution (two s } \\
\text { authors with } \\
\text { ntified as ind }\end{array}$ & $\begin{array}{l}\text { vestigator applie } \\
\text { rize, the investiga } \\
\text { won a prize, the } \\
\text { an author was aff } \\
\text { h cases occurred). } \\
\text { a institutional aff } \\
\text { pendent or for wl }\end{array}$ & $\begin{array}{l}\text { he following rules. If } \\
\text { counted one prize fo } \\
\text { estigator counted or } \\
\text { ated with two instit } \\
\text { vo hundred ninety-th } \\
\text { tion; thirty-six prize } \\
m \text { the investigator cc }\end{array}$ & $\begin{array}{l}\text { wo or more co- } \\
\text { hat institution. } \\
\text { prize for each } \\
\text { ions, the prize } \\
\text { prize-winning } \\
\text { winning books } \\
\text { ld not find an }\end{array}$ \\
\hline
\end{tabular}

Source: See endnote 4. 


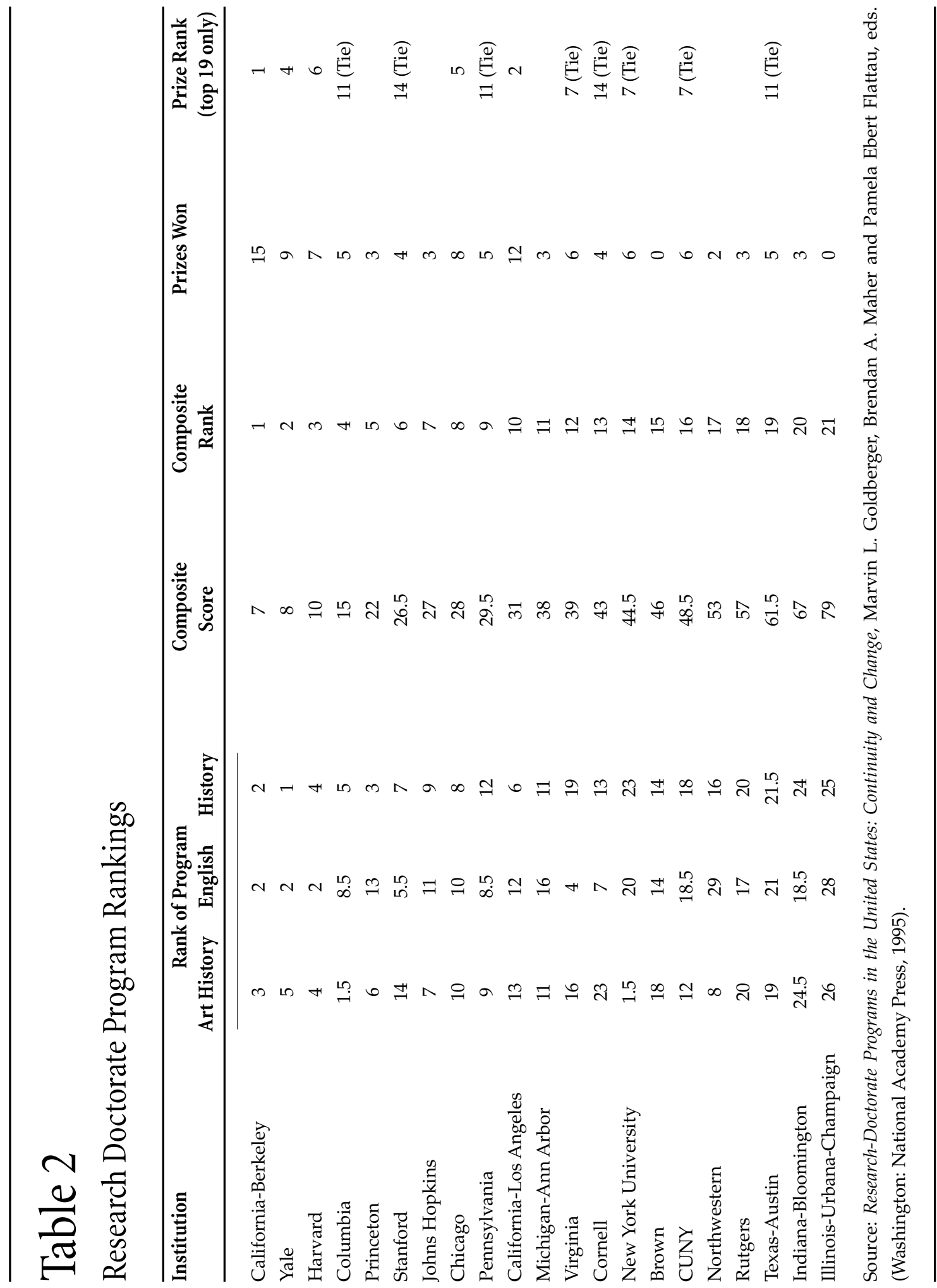


an institutional ranking derived from the National Research Council's Research-Doctorate Programs in the United States: Continuity and Change (1995). ${ }^{7}$ Research-Doctorate Programs has rankings for history and art history programs that parallel this study's coverage of AHA and CAA prizes. At the risk of oversimplification, Research-Doctorate Programs' ranking of English departments can be taken to parallel MLA's prizes. ResearchDoctorate Programs ranks music programs, but such programs include so much more than musicology that their rankings cannot be included here. By assigning one point for each place ranking in Research-Doctorate Programs (e.g., three points for a third place ranking) for art history, English, and history, we can compile a composite ranking (table 2). The composite ranking includes only institutions that have all three programs in the top thirty.

Given the composite rankings cover only three of the four fields and given that awards for an institution's books are only one factor in judging a humanities program, there is remarkable coincidence between the composite ranking and the institutional prize totals. First, California-Berkeley heads both lists. Furthermore, Yale, Harvard, Chicago, and UCLA are in the top ten in both and places six through twenty on both lists are shared by Stanford, Pennsylvania, Virginia, Cornell, NYU, CUNY, and Texas at Austin. Columbia, fourth in the composite ranking, is tied for eleven in prizes. Most of the other institutions in the composite top twenty had at least three prizes. Of institutions, not in the composite ranking, that won more than one prize from a given association, Duke's history program ranked fifteen, its English 5.5, French third; and Spanish and Portuguese second. California-Santa Barbara's English program ranked 34.5; German twenty-four, and Spanish and Por-

Noteworthy among the NRC composite and prize rankings is the predominance of private institutions, the high places of the University of California campuses notwithstanding. tuguese 20.5. Iowa's history program ranked 29.5. Ohio State's English program ranked thirty-three, French 30.5, German seventeen; and Spanish and Portuguese thirty-three. WisconsinMadison's history program ranked tenth.

Noteworthy among the NRC composite and prize rankings is the predominance of private institutions, the high places of the University of California campuses notwithstanding. This is especially

true among the top ten in tables 1 and 2. Private universities outnumber non-University of California public universities five to two in the top ten prize-winners and eight to zero in the top ten NRC composite. Among the nineteen listed prize-winning schools, ten are private and nine public, including the three California campuses. Twelve private and nine public (including Berkeley and UCLA) institutions constitute the top of the NRC composite.

\section{Prize-winning Publishers}

The distribution of prizes among publishers is more concentrated than for institutions. Eighteen presses-20.5 percent of all prize-winning publishers-published 72 percent 
Table 3

Prize-winners by Publisher

\begin{tabular}{|c|c|c|c|c|c|}
\hline Publisher & Total & Art & History & Literature & Musicology \\
\hline California & 27 & 0 & 13 & 12 & 2 \\
\hline Cambridge & 26 & 1 & 15 & 6 & 4 \\
\hline Princeton & 23 & 4 & 13 & 6 & 0 \\
\hline Cornell & 21 & 0 & 9 & 12 & 0 \\
\hline Chicago & 20 & 4 & 4 & 9 & 3 \\
\hline Oxford & 17 & 0 & 6 & 10 & 1 \\
\hline North Carolina & 16 & 0 & 15 & 1 & 0 \\
\hline Stanford & 16 & 0 & 7 & 9 & 0 \\
\hline John Hopkins & 15 & 0 & 8 & 7 & 0 \\
\hline Harvard & 12 & 0 & 9 & 1 & 2 \\
\hline Duke & 8 & 0 & 0 & 8 & 0 \\
\hline Nebraska & 8 & 0 & 1 & 7 & 0 \\
\hline Yale & 8 & 1 & 3 & 4 & 0 \\
\hline Michigan & 6 & 0 & 2 & 4 & 0 \\
\hline Columbia & 4 & 0 & 1 & 3 & 0 \\
\hline Minnesota & 4 & 0 & 0 & 4 & 0 \\
\hline Norton & 4 & 1 & 3 & 0 & 0 \\
\hline Texas & 4 & 1 & 0 & 3 & 0 \\
\hline 6 with 3 & 18 & & & & \\
\hline 11 with 2 & 22 & & & & \\
\hline 54 with 1 & 54 & & & & \\
\hline TOTAL & 333 & & & & \\
\hline \multicolumn{6}{|c|}{$\begin{array}{l}\text { For books published simultaneously in the U.S. and elsewhere, only the U.S. publisher is counted. } \\
\text { Five books were co-published in the U.S. Thus the total is five greater than the number of prize- } \\
\text { winners. }\end{array}$} \\
\hline \multicolumn{6}{|c|}{ Source: See endnote 4.} \\
\hline \multicolumn{6}{|c|}{$\begin{array}{l}\text { of the prize-winning books. Table } 3 \text { summarizes the data. California leads the way again } \\
\text { with the University of California Press publishing twenty-seven prize-winning books. } \\
\text { Interestingly, only one trade publisher, Norton, is in the top eighteen. Two other trade } \\
\text { publishers, Hill \& Wang and Knopf, had three prize-winners, all in history. Remark- } \\
\text { ably, Hill \& Wang published Linda Kerber's No Constitutional Right to be Ladies (1998), } \\
\text { which won both the Kelly and Littleton-Griswold Prizes of the AHA; and Knopf pub- } \\
\text { lished Laura Thatcher Ulrich's Midwife's Tale, which won the AHA's Dunning and Kelly } \\
\text { prizes. }\end{array}$} \\
\hline
\end{tabular}


Other research reported in the library literature offers indicators of the quality of university press publications and those of trade publishers. Edward A. Goedeken found that between 1983 and 1992 the percentage of academic presses whose books received an "Outstanding Academic Book" award from Choice rose from 33 to 48 percent of all publishers. ${ }^{8}$ In the present study university presses are 47 percent of all publishers whose books won prizes. But this proportion hides the fact that 84 percent of the books receiving prizes are from university presses. In late 1994/early 1995, Paul Metz and John Stemmer asked collection development librarians to rate the quality of sixty-four publishers, including six university presses. ${ }^{9}$ Among the six were Cambridge, Oxford, Stanford, and Harvard, which each had twelve or more awards from the humanities associations, far more than any trade publisher. These four had the highest quality rankings. The other two university presses in the Metz/Stemmer study-Oklahoma and State University of New York-each had one prize-winner and their quality rankings are close to those of the trade publishers that won one to three prizes.

\section{Disciplinary and Cross-Disciplinary Trends}

There is evidence that in the closing decades of the twentieth century, literary studies had great influence on other areas of humanities scholarship. ${ }^{10}$ This may be true on some levels, but in terms of library acquisitions as seen in OCLC holdings, literature prize-winners are far behind the other disciplines (table 4). Furthermore, there is little recognition of books focusing on literary topics by the prize juries of other disciplines. The College Art Association awarded one of its twenty-two prizes to a book that classed in P-PZ, the Library of Congress (LC) classification for languages and literatures. The American Historical Association also awarded one prize (of 145) to a book that classed in P-PZ. The American Musicological Society awarded none. However, the Modern Language Association gave two prizes each to books in art and musicology and sixteen (11 percent) to books that classed in history (LC classification C-F). This suggests that history may have been having an effect on literary studies, but not the other way around. As for those who contend that the visual arts are taking an increasingly important role in society and scholarship (possibly at the expense of traditional texts), the comparatively strong OCLC holdings for prize-winners in art scholarship suggest this may indeed be true. ${ }^{11}$

\section{Table 4}

\section{OCLC Holdings of Prize-winners by Awarding Association}

\begin{tabular}{cccc}
\hline Awarding Association & Average Holdings & Median Holdings & Range of Holdings \\
\hline AHA & 558 & 433 & 3 to 2120 \\
CAA & 501 & 514 & 141 to 828 \\
AMS & 501 & 459 & 145 to 1232 \\
MLA & 367 & 310 & 26 to 1130 \\
Source: OCLC, September 1, 2001. & & \\
\hline
\end{tabular}


The subject distribution as seen in the LC classification numbers assigned to prizewinners indicates there is a great deal of cross-disciplinary interest in history, but much less to none in other disciplines. In LC classification art is N-NX, history C-F, literature $\mathrm{P}-\mathrm{PZ}$, and musicology M-MT. Table 5 shows that a very substantial percentage of prizewinners in history class in social sciences (G-LT). Of these, a slightly higher percentage

\section{Table 5}

\section{Subject Distribution of Prize-winners by Library of Congress Classification}

\begin{tabular}{lcccccc}
\hline $\begin{array}{c}\text { Awarding } \\
\text { Assoc. }\end{array}$ & $\begin{array}{c}\text { Art } \\
(\mathrm{N}-\mathrm{NX})\end{array}$ & $\begin{array}{c}\text { History } \\
(\mathbf{C}-\mathrm{F})\end{array}$ & $\begin{array}{c}\text { Literature } \\
(\mathbf{P}-\mathrm{PZ})\end{array}$ & $\begin{array}{c}\text { Musicology } \\
(\mathrm{M}-\mathrm{MT})\end{array}$ & $\begin{array}{c}\text { Social Science } \\
(\mathbf{G}-\mathrm{LT})\end{array}$ & Other \\
\hline CAA & $91 \%$ & 0 & $5 \%$ & 0 & 0 & $5 \%$ \\
AHA & $1 \%$ & $48 \%$ & $1 \%$ & $1 \%$ & $41 \%$ & $9 \%$ \\
MLA & $1 \%$ & $11 \%$ & $73 \%$ & $1 \%$ & $5 \%$ & $8 \%$ \\
AMS & 0 & 0 & 0 & $100 \%$ & 0 & 0
\end{tabular}

Not all row totals equal $100 \%$ because of rounding.

Source: OCLC

of books fall into economics (14 percent for HB-HJ) than into sociology (12 percent for HM-HX). The presence of economic topics is striking for some have contended that the quantitative turn in economic history to "cliometrics" lessened the interest in economic history among the larger discipline. ${ }^{12}$ Literary prize-winners include about a tenth that class as history and 5 percent social science, but otherwise there is no noteworthy concentration outside the home field. Art prize-winners are almost entirely within the discipline, and musicology prize-winners are entirely within their discipline. Interestingly, more than half of the

Interestingly, more than half of the twenty prize-winners most widely recorded on OCLC classify in history, including one book that won a prize from the MLA. twenty prize-winners most widely recorded on OCLC classify in history, including one book that won a prize from the MLA (table 6). Four of the most widely recorded history prize-winners class among the social sciences in the LC classification (with LC classifications of GB, HQ, JK, KF), two in religion (BL, BX); two in music (both $\mathrm{ML}$ ); and one in literature (PS). All this suggests that among broad areas of humanities scholarship history (C-F) has the greatest potential for large library acquisitions. 


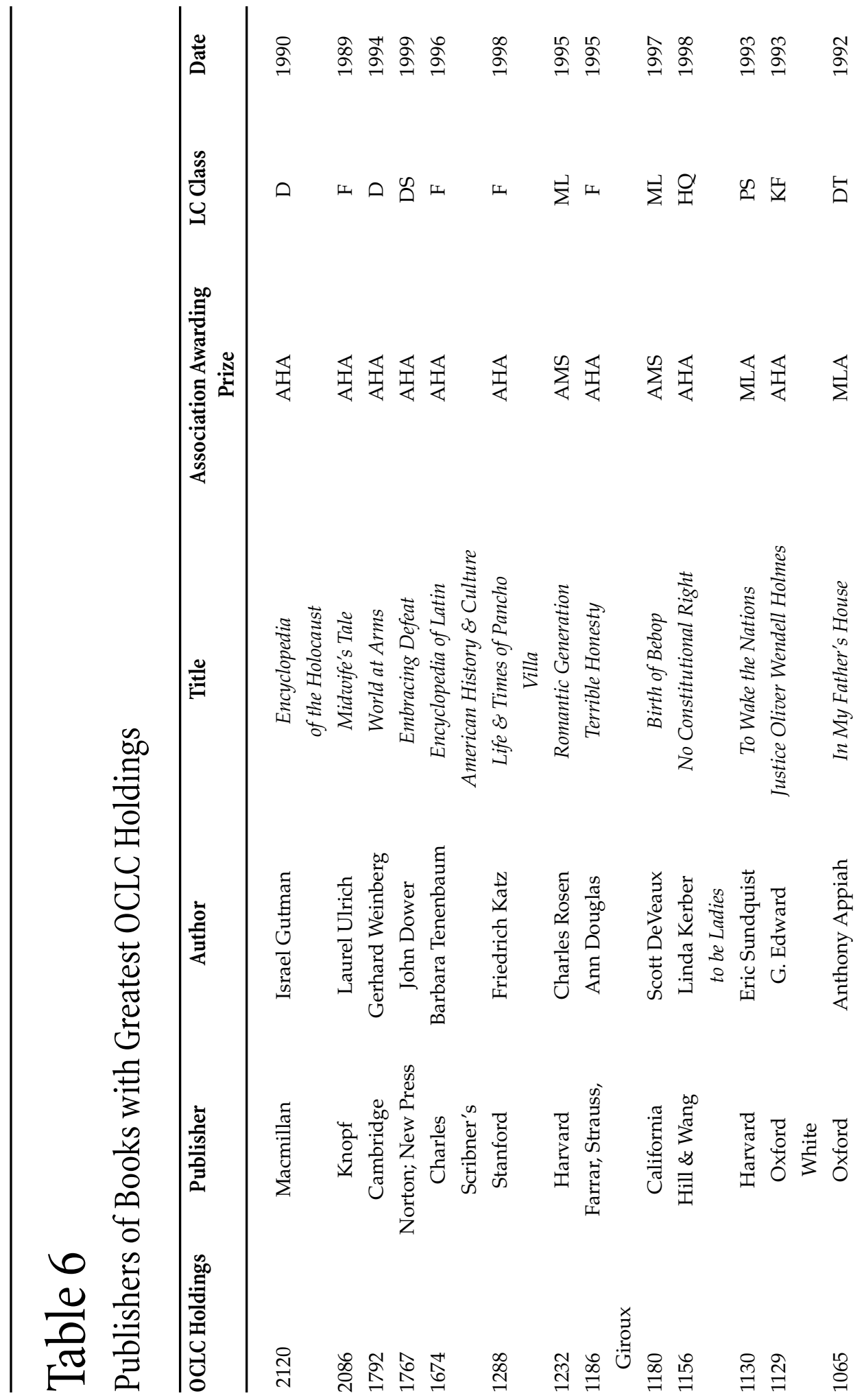




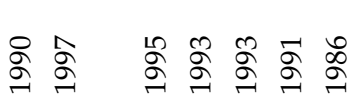

苞怘山杀光山

余要要要要要要

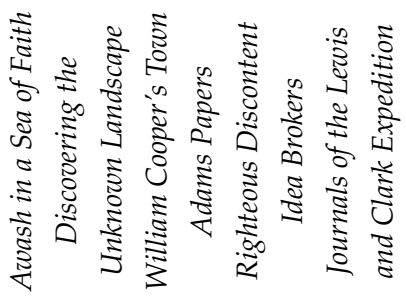

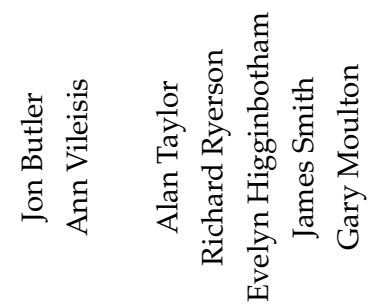

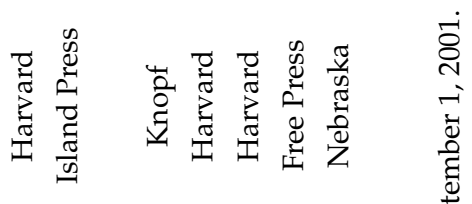
के

Uु

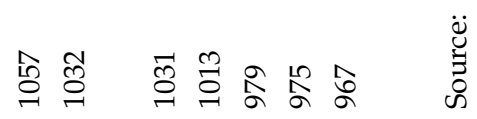




\section{OCLC Holdings of Prize-winners}

Trade publications appear to be heavily acquired by libraries. Of the twenty books with the most OCLC holdings, nearly half are from trade publishers (table 6). It is worth mentioning that in terms of OCLC holdings, the very top humanities prize-winners compare well with bestsellers. The top ten mid-decade (1996) bestsellers from infoplease.com averaged 2586 (median 2521) OCLC holdings on September 1, 2001, with a range of 1653 to 3587 . Five of the prize-winners fall within this range. However, the typical humanities prize-winner is far from a bestseller: the overall average holdings for all awardees is 463, the median 365. (These numbers include all OCLC records, including those for translations, paperback editions, and the like.) Since most academic libraries belong to OCLC, the data found here reinforce the point that academic publishers can no longer count on substantial sales to academic libraries of any book they produce. Finally, OCLC holdings of prize-winners are in line with findings of John M. Budd and Catherine K. Craven about holdings of humanities titles of Choice's Outstanding Academic Books. Budd and Craven found significant declines in acquisitions by almost all sizes of academic libraries between 1984-1985 and 1995 of books in English and American literature and North American history. (The only exception was acquisitions of North American history by the largest libraries. ${ }^{13}$ ) AHA, AMS, CAA, and MLA prize-winners published in 1992 or earlier average 526 holdings (median 441); those published from 1993 to 1995 average 461 (median 367); from 1996-1998, 432 (median 337). In other words, those figures suggest library holdings have declined roughly 20 percent.

Examination of library holdings of prize-winners suggests that few books have numerous holdings unless there are a substantial number of nonacademic libraries among those holdings. At the same time, the extent of nonacademic library holdings suggests, among other things, how much a book appeals to and is accessible to the general public and how much a publisher markets a book outside the academy. Given that there are more than 330 prize-winners and each is held by an average of more than 460 libraries, the investigator had to limit analysis of nonacademic library holdings to selected books and a restricted group of libraries. (Nonacademic libraries here mean those that are not part of degree-granting institutions.) In selecting books the investigator had two principal questions in mind:

1) Did books that had a higher total number of holdings tend to have a higher percentage of nonacademic library holdings?

2) Did some fields have a higher percentage of nonacademic library holdings than others?

The investigator also divided the population into eight different levels of holdings with approximately forty books in each level. He then selected at random from each level 1) two trade books from any field; 2) two history and two literature books from university presses; and 3) one CAA and one AMS award winner from any kind of press. (Because trade, CAA, and AMS books could overlap, the number of books for each level could range from six to eight. The total was sixty-three.) If a given kind of book was not available for a particular level, the investigator returned to the unsampled members of 
that kind (e.g. all AMS winners) not yet in the sample from the nearest higher level. To estimate the proportion of nonacademic library holdings, the investigator used holdings provided by OCLC's WorldCat for six midwestern states - Illinois, Indiana, Iowa, Kentucky, Missouri and Wisconsin. These states include a good mix of urban, suburban, and rural populations and presumably library types. The overall results are depicted by figure 1, which shows that, in general, the larger the number of OCLC holdings, the higher the likelihood many of those holdings will be of non-academic libraries.

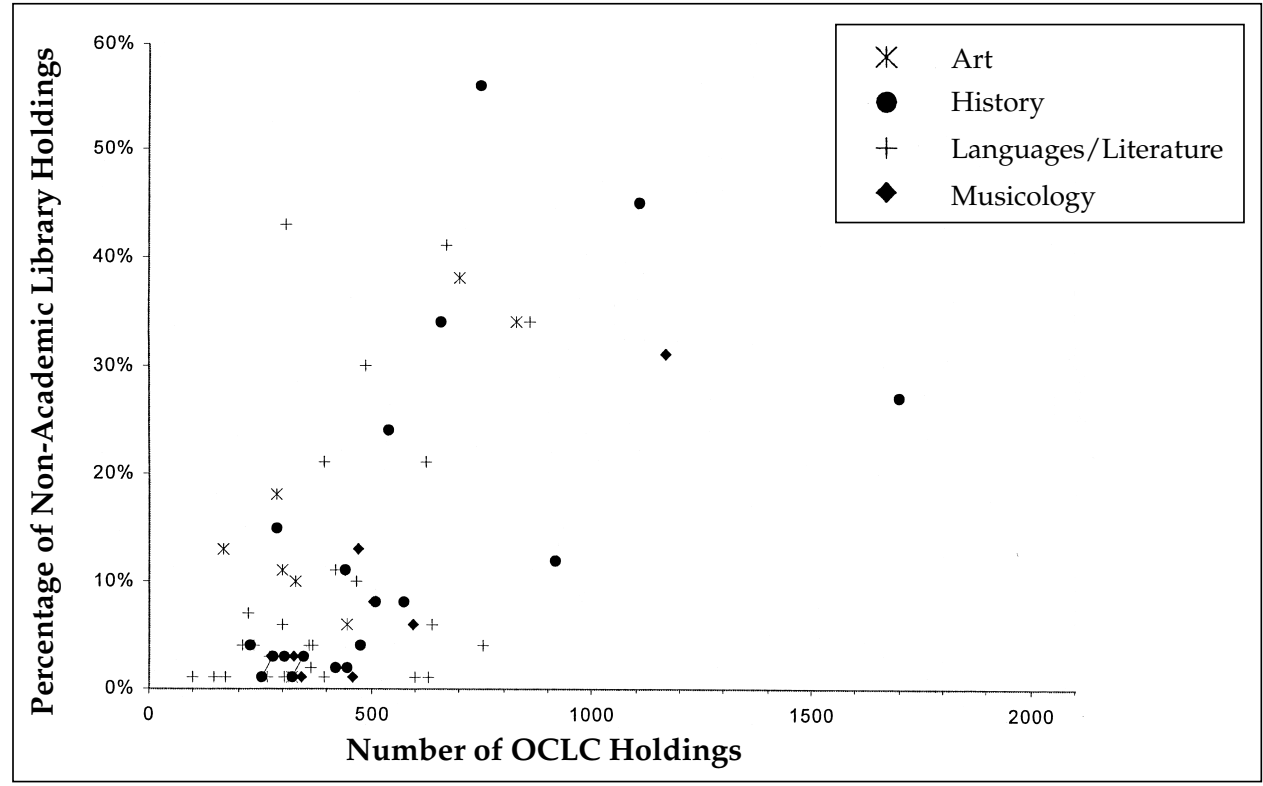

Figure 1. Percentage of Non-Academic Library Holdings on OCLC by Number of Holdings

Furthermore, examination of all books with more than 500 holdings and those with fewer than 400 shows that AHA, AMS, and CAA winners are disproportionately represented among those with greater than 500 holdings; while MLA awardees are disproportionately represented among those with fewer than 400 holdings. AHA books are 44 percent of the population and 56 percent of those with more than 500 holdings; AMS has 4 percent of the population, 5 percent of those with more than 500 holdings; CAA 7 percent of all, 11 percent of those with more than 500 holdings. MLA prize-winners are 45 percent of the population, and 58 percent of those with fewer than 400 holdings.

\section{Electronic Versions of Prize-winners}

OCLC offers data on the availability of books through netLibrary. netLibrary, launched in 1999, then described itself as the "leading provider of eBooks." It aimed to provide "a comprehensive collection of reference, scholarly, and professional electronic books."14 Overall, 15 percent of the prize-winners were among netLibrary's OCLC holdings on 
September 1, 2001. (About a month later netLibrary reported financial distress. ${ }^{15} \mathrm{In}$ early December 2001, a systematic random sample of fifty of the 328 winning books revealed no titles acquired by netLibrary since September, but, for several already offered by netLibrary, the electronic edition had more OCLC holdings than in September.) Just as the University of California Press had the most prize-winners overall, so too it had the most accessible through netLibrary, twenty-two of its twenty-seven. California had by far the most, as the next greatest was five of the University of North Carolina Press's sixteen. netLibrary also mounted all three of the University of Pennsylvania Press's winners. Otherwise, most presses were represented, if at all on September 1 , by just one or two books. Notably missing from the netLibrary collection were publishers that had more than five prize-winners: from Cambridge University Press's twentysix to the University of Michigan Press's six. (See tables 3 and 7). Also notable among the missing were trade publishers. Among the forty trade prize-winners, only one of Routledge's two awardees was among OCLC holdings for netLibrary.

No AMS or CAA prize-winner was made available by netLibrary, but 15 percent of MLA and 19 percent of AHA winners were. Another way to view the subject distribution of netLibrary is in terms of LC class numbers. Thirty-three percent of prize-win-

\section{Table 7}

\section{Publishers Providing Award-Winning Books for netLibrary}

\begin{tabular}{lcc}
\hline Publisher & Number of netLibrary Titles & Number of Prize-winners \\
\hline California & 22 & 27 \\
North Carolina & 5 & 16 \\
Pennsylvania & 3 & 3 \\
Indiana & 2 & 3 \\
Southern Illinois & 2 & 2 \\
Stanford & 2 & 16 \\
Yale & 2 & 8 \\
Chicago & 1 & 20 \\
Columbia & 1 & 4 \\
Harvard & 1 & 12 \\
Massachusetts & 1 & 1 \\
MIT & 1 & 1 \\
Nebraska & 1 & 8 \\
Oklahoma & 1 & 1 \\
Oxford & 1 & 17 \\
Routledge & 1 & 2 \\
SUNY & 1 & 1 \\
Texas & 1 & 4 \\
Source: OCLC, September 1, 2001 & & \\
\hline
\end{tabular}


ners class were in LC classification P-PZ (literature); 26 percent in C-F (history); 21 percent in G-LT (social science); 7 percent N-NX (art); 5 percent M-MT (music); and 8 percent all others. (Percentages exceed 100 percent because of rounding.) Table 8 compares percentages of these class groups among all prize-winners with those made available from netLibrary. The most notable difference is that netLibrary did not mount a single book that classes in art (N-NX). Most art books contain a large number of images, and rights to reproduce them are usually held by their owners, not the copyright holder of the book. Perhaps the difficulty of contacting numerous rights holders dissuaded netLibrary from pursuing art books. Besides an absence of art books, literature prizewinners (P-PZ) are underrepresented (33 percent of all prize-winners; 27 percent of netLibrary offerings.) On the other hand, history (C-F) and social science (G-LT) titles are more heavily represented in netLibrary than among the population of prize-winners.

\section{Table 8}

\section{Prize-winners Available through netLibrary by LC Class}

\begin{tabular}{lcc}
\hline LC Class Range & $\begin{array}{c}\text { Percentage of Class among all } \\
\text { Prize-winners }\end{array}$ & $\begin{array}{c}\text { Percentage of Class among all netLibrary- } \\
\text { available Prize-winners }\end{array}$ \\
\hline C-F (history) & 26 & 35 \\
G-LT (social science) & 21 & 29 \\
M-MT (music) & 5 & 2 \\
N-NX (art) & 7 & 0 \\
P-PZ (literature) & 33 & 27 \\
Other & 8 & 8
\end{tabular}

Column totals may exceed $100 \%$ because of rounding.

Source: OCLC.

\section{Conclusion}

Study of prize-winning books from four major scholarly associations in the humanities reinforces some things that are well known, points toward recently identified developments, and offers insight into new phenomena. First, the data confirm there is little coauthorship in the humanities. Second, library holdings of prize-winners declined during the 1990s. Third, most prize-winning scholarship comes from major university presses and the largest, traditionally dominant research universities. Interestingly, there is greater concentration of prize-winners among university presses than there is among universities. And, through all the rankings, the University of California, especially its Berkeley campus and the university's press stand out. Geographically, one might say 
that California and the eastern seaboard from Duke to Harvard dominate. Furthermore, except for University of California campuses, private universities outnumber public universities at the top of the prize list.

\section{Interestingly, there is greater concentration of prize-winners among university presses than there is among universities.}

While university press books overwhelm trade books in the total population of prize-winners, trade publishers are exceptionally represented among books with the greatest number of OCLC holdings. Trade books, on the other hand, are almost completely missing from the books that have been made accessible by netLibrary.

Prize-winners from the AHA, AMS,

and CAA average greater numbers of OCLC holdings than those from the MLA. History books are preeminent among the most-held prize-winners. History prize-winners include many books with a social science focus (LC classification G-L) and the MLA gave about one-tenth of its prizes to books that class in history (LC classification C-F). Otherwise, most scholarly associations give prizes largely to books that class in their own discipline. (E.g. all AMS winners class in LC classification's M-MT.)

Receipt of a prize from the AHA, AMS, CAA, or MLA is cause for a winning humanist to celebrate, but two key findings of this study are no reason for general celebration among humanists. First, library acquisitions of books, the principal medium of communication in the humanities, appear to be in decline. Second, a major provider of electronic books filed for bankruptcy, and even when financially healthy, it supplied only 15 percent of, arguably, the most important humanities scholarship of the decade.

Certainly leaders in the humanities in the United States are well aware of the importance of making humanities books available online. The American Council of Learned Societies has launched "The History E-Book Project" to provide through the Web digital versions of books published on paper and create born-digital books that take full advantage of current technology. ${ }^{16}$ Viewed from the perspective of the present study, the choice of history is wise. History is a larger discipline than art history and musicology - there are 111 ranked history doctoral programs in contrast to thirty-eight for art history and sixty-five for music that includes more than musicology. Literary studies surpasses history in size of discipline (127 doctoral programs for English alone). ${ }^{17}$ But, if OCLC holdings are any index, books in literary studies attract a third less interest than do books of history ( $475 \mathrm{v} .308$ median holdings for books in LC classification D-F [history] and P-PZ [literary studies] respectively). In short the size of the field of history and the greater library holdings of its books than those of literary studies suggests history books online will attract larger audiences (and presumably better revenue streams) than books from other humanities disciplines. Furthermore, because history books do not necessarily involve images, they do not generally require the extensive copyright permissions needed by books of art scholarship. The History E-Book Project will need all the advantages it can muster because the health of the scholarly book has declined as academic libraries spend an increasing percentage of their budgets on subscriptions for journals and licenses for electronic resources. 
Stephen E. Wiberley, Jr. is Bibliographer for the Social Sciences and Professor, University Library, University of Illinois at Chicago; he may be contacted via e-mail at: wiberley@uic.edu.

The author wishes to thank Deborah D. Blecic, John Cullars, Joan B. Fiscella, Jean Wiberley, and librarians at Columbia College Chicago for their advice and assistance.

\section{Notes}

1. John Cullars, "Citation Characteristics of French and German Literary Monographs," Library Quarterly 59 (October 1989): 305-25; John Cullars, "Citation Characteristics of Monographs in the Fine Arts," Library Quarterly 62 (July 1992): 325-42; John Cullars, "Citation Characteristics of French and German Fine Arts Monographs," Library Quarterly (April 1996): 138-60.

2. Stephen E. Wiberley, Jr. and William G. Jones, "Humanists Revisited: A Longitudinal Look at the Adoption of Information Technology," College \& Research Libraries 55 (November 1994): 499-509.

3. Roger G. Baldwin and Ann E. Austin, "Toward Greater Understanding of Faculty Research Collaboration," The Review of Higher Education 19 (Fall 1995): 45-70.

4. Perspectives: Newsletter of the American Historical Association 29 (Feb. 1991): 14-16; 30 (Feb. 1992): 6-9; 31 (Feb. 1993): 14-16; 32 (Feb. 1994): 11-16; 33 (Feb. 1995): 21-24; 34 (Feb. 1996): 16-18; 35 (Feb. 1997): 16-21; 36 (Mar. 1998): 17-22; 37 (Mar. 1999): 18-21; 38 (Mar. 2000): 3337. PMLA 116 (Sept. 2001): 832-843. "American Musicological Society, The Otto Kinkeldey Award," available: <http://www.sas.upenn.edu/music/ams/kinkeldeywinners.html> [April 3, 2002]. College Art Association, "The Alfred H. Barr Jr. Award for Museum Scholarship," available:<http://www.collegeart.org/caa/aboutcaa/barr.html> [April 3, 2002]. College Art Association, "The Charles Rufus Morey Book Award," available: <http:// www.collegeart.org/caa/aboutcaa/morey.html> [April 3, 2002].

5. Judith Weedman, "On the 'Isolation' of Humanists-A Report of an Invisible College," Communication Research 20 (Dec. 1993): 749-776.

6. Clara M. Chu, "The Scholarly Process and the Nature of the Information Needs of the Literary Critic: A Descriptive Model," (Ph.D. diss., University of Western Ontario, 1992): 85.

7. Research-Doctorate Programs in the United States: Continuity and Change, ed. Marvin L. Goldberger, Brendan A. Maher and Pamela Ebert Flattau. (Washington, D.C.: National Academy Press, 1995).

8. Edward A. Goedeken, "An Index to Publisher Quality Revisited: A Partial Replication," Library Acquisitions: Practice \& Theory 17 (1993): 263-268.

9. Paul Metz and John Stemmer, "A Reputational Study of Academic Publishers," College $\mathcal{E}$ Research Libraries 57 (May 1996): 234-247.

10. M. H. Abrams, "The Transformation of English Studies: 1930-1995." Daedalus 126 (Winter 1997): 105-31; John E. Toews, "Intellectual History after the Linguistic Turn: The Autonomy of Meaning and the Irreducibility of Experience," American Historical Review 92 (Oct., 1987): 879-907.

11. John H. D'Arms, "Funding Trends in the Academic Humanities, 1970-1995: Reflections on the Stability of the System" in What's Happened to the Humanities? ed. Alvin Kernan (Princeton: Princeton University Press, 1997), 32-60.

12. Naomi R. Lamoreaux, "Economic History and the Cliometric Revolution" in Imagined Histories: American Historians Interpret the Past, ed. Anthony Molho and Gordon S. Wood (Princeton: Princeton University Press, 1998), 59-84.

13. John M. Budd and Catherine K. Craven, "Academic Library Monographic Acquisitions: Selection of Choice's Outstanding Academic Books," Library Collections, Acquisitions, E Technical Services 23, No. 1 (1999): 15-26. 
14. "netLibrary Launches the World's Most Comprehensive Library on the Internet" (press release, March 29, 1999).

15. “OCLC Offers to Buy netLibrary," American Libraries 33 (Jan. 2002): 34.

16. Available: <http://www.historyebook.org/> [April 3, 2002].

17. Research-Doctorate Programs in the United States, 478-79; 535-39; 550-53; 575-77. 